\title{
Fish-Zooplankton-A Predator-Prey Relations as a Key Factor for the Design of Zooplankton Distribution Sampling Program in Lake Kinneret, Israel
}

\author{
Moshe Gophen \\ Migal-Scientific Research Institute, Kiryat Shmone, Israel \\ Email: Gophen@Migal.org.il
}

How to cite this paper: Gophen, M. (2017) Fish-Zooplankton-A Predator-Prey Relations as a Key Factor for the Design of Zooplankton Distribution Sampling Program in Lake Kinneret, Israel. Open Journal of Modern Hydrology, 7, 209-222. https://doi.org/10.4236/ojmh.2017.73012

Received: May 22, 2017

Accepted: July 23, 2017

Published: July 26, 2017

Copyright $\odot 2017$ by author and Scientific Research Publishing Inc. This work is licensed under the Creative Commons Attribution International License (CC BY 4.0).

http://creativecommons.org/licenses/by/4.0/

\section{(c) (i) Open Access}

\begin{abstract}
Long-term data record of Kinneret Epilimnetic Zooplankton biomass distribution and fish stock assessment was analyzed. The objective is aimed at defining the representativeness of the present sampling stations distribution for the measure of the entire Lake Kinneret zooplankton biomass. Previous studies documented the preeminence of temperature and fish predation impacts on zooplankton density: water temperature through growth rate trait and fish predation. Acoustic surveys indicated that fish shoals are mostly inhabiting the Peripheral region and much less the central part of the Kinneret pelagial. Due to fish zooplanktivory, densities of planktonic crustacean in the Pelagial periphery presented by $5-7$ sampling stations are low. Nevertheless, large central lake area with higher densities of zooplankton biomass is presented by only one station. Therefore, stations average is incorrect as is total lake measure. The average result as indicated presently as total zooplankton biomass in lake Kinneret is, therefore, underestimated. Two optional corrective suggestions are concluded: 1) Additional sampling stations in the central part of the Pelagial region; 2) Usage of station value of aerial coefficient (promoter).
\end{abstract}

\section{Keywords}

Kinneret, Zooplankton, Fish, Sampling Program

\section{Introduction}

The long-term Record of Zooplankton, as part of the scientific routine comprehensive limnological research of the Lake Kinneret ecosystem [1], was started by the team of Kinneret Limnological Laboratory, Israel Oceanographic and Lim- 
nological Research Company Ltd., in 1969. The responsibility of the author of this paper was the Zooplankton study. Location of sampling stations was fixed within the routine sampling program (Figure 1): the principal station at the deepest point and 5 - 7 other stations were fixed according to bathymetrical sutures at $15-25 \mathrm{~m}$ and one at $10 \mathrm{~m}$ depth. Consideration was given to the Epilimnion thickness during stable Thermal stratification and the Thermocline is allocated at the shallowest depth. When Thermocline is allocated at the shallowest depth, hypolimnetic samples could be collected only at the central (A) and 1 or 2 other deep stations if WL is high enough. The reason for allocation of sampling stations was defined by bathymetry (depth contour lines) (Figure 1). Additional requirements were considered for allocation of sampling station, such as the Jordan River inlet and outlet or sub-lacustrine salty spring inflows or the Intake of the National Water Carrier. Nevertheless, fish distribution was not concluded in the consideration of the sampling station spatial distribution. Moreover, the study of fish distribution in Lake Kinneret and stock assessment by Acoustic Technology was initiated almost 20 years later [2] [3]. In this paper, the impact of the relationships between the zooplankton biomass density (LKDB 1969-2016) and fish assemblage distribution on sampling program design is discussed. Two periods were analyzed: 1) 1969-1985; 2) 1986-1995. The reason for the split between these two periods is technical: the formal data set of the $1^{\text {st }}$ period include partial Hypolimnetic sampling and it was necessary to remove hypolimnetic data (below Thermocline); after 1985 due to financial limitations

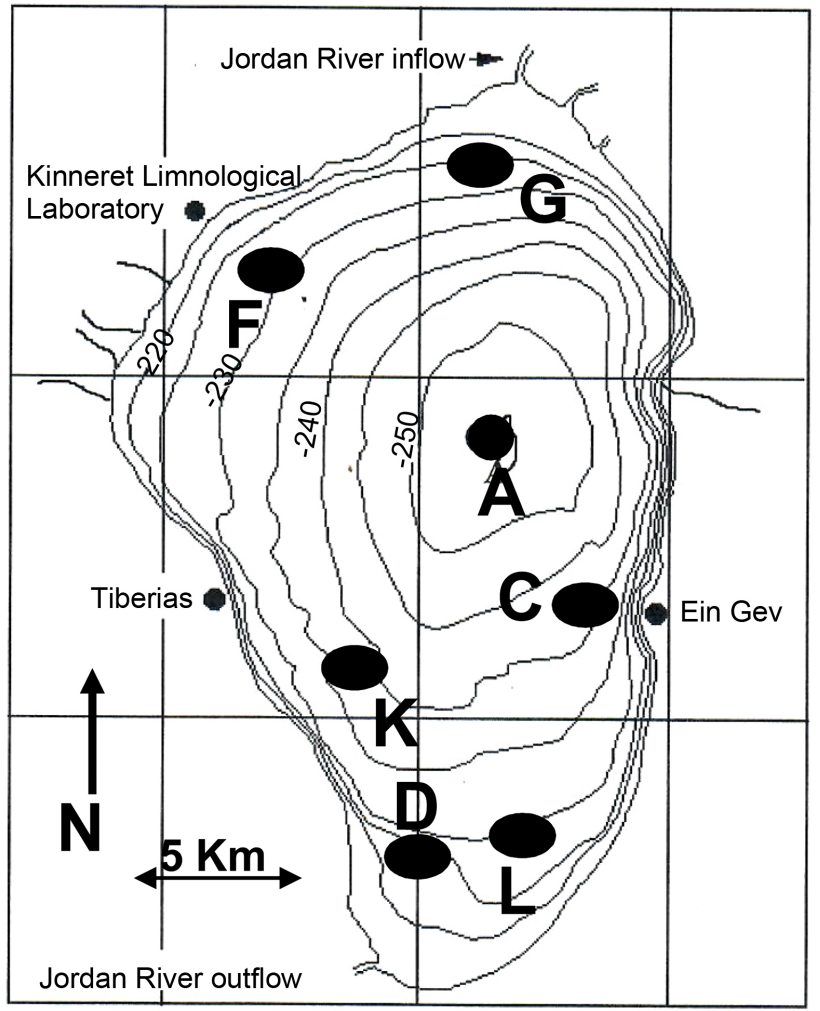

Figure 1. Sampling stations (A)-(G) in lake Kinneret. 
reduction of sampling stations was essential. Daily Spatial and Bathymetrical distributions of zooplankton in Lake Kinneret were previously studied as well as zooplankton ecological trait and diurnal migrations were previously documented [1] [4]-[11]. The present paper represents a long term (1969-2015) analysis of the related distributions of fish and zooplankton.

\section{Material and Methods}

The zooplankton sampling procedure is given in Gophen [11] and Gophen and Azoulay [12]. The data in tables $1 \& 2$ illustrate the sampling capacity and statistical evaluation (mean) of zooplankton (Table 1-annually; Table 2-monthly) in Lake Kinneret during 1969-1985. The spatial definitions of the station locations are Periphery: C, G, F, K, D, L; Center: A; North: F, G, C; South: K, D, L (Figure 1). All data discussed in this paper were due to a similar water layer thickness (Epilimnion) and are, therefore, feasibly comparative. The documented reports of the original zooplankton raw date were recorded and computerized on tapes

Table 1. Annual means (all stations, all dates) of Zooplankton Biomass and annual means of C.V. (see text) and total number of sampled stations, in Lake Kinneret during 19691985.

\begin{tabular}{|c|c|c|c|}
\hline Year & $\begin{array}{l}\text { All Stations Annual } \\
\text { Mean Zooplankton } \\
\text { Biomass }\left(\mathrm{g}(\mathrm{ww}) / \mathrm{m}^{2}\right)\end{array}$ & $\begin{array}{l}\text { Total Number of } \\
\text { Sampled Stations }^{@}\end{array}$ & $\begin{array}{l}\text { Annual Mean } \\
\text { C.V. } \times 10^{-2} \\
(\text { see text })^{\star}\end{array}$ \\
\hline 1969 & 42 & 204 & 50 \\
\hline 1970 & 51 & 131 & 50 \\
\hline 1971 & 41 & 109 & 42 \\
\hline 1972 & 33 & 132 & 43 \\
\hline 1973 & 39 & 105 & 42 \\
\hline 1974 & 36 & 125 & 47 \\
\hline 1975 & 28 & 95 & 40 \\
\hline 1976 & 32 & 85 & 38 \\
\hline 1977 & 35 & 74 & 41 \\
\hline 1978 & 33 & 74 & 36 \\
\hline 1979 & 33 & 71 & 33 \\
\hline 1980 & 36 & 73 & 45 \\
\hline 1981 & 27 & 69 & 48 \\
\hline 1982 & 32 & 75 & 39 \\
\hline 1983 & 23 & 102 & 49 \\
\hline 1984 & 25 & 84 & 34 \\
\hline \multirow[t]{2}{*}{1985} & 19 & 157 & 59 \\
\hline & Grand Mean 33 & $\begin{array}{l}\text { Total Number of Sampled } \\
\text { Stations:1765 }\end{array}$ & Grand Mean 43 \\
\hline
\end{tabular}

${ }^{\circledR}$ Each sampled Station is a subsample removed from mixed 7 samples collected; total samples collected at fixed depth during 1969-1985 was app. $1765 \times 7=12,355 .{ }^{*}$ C.V. $=$ Coefficient of Variation. 
Table 2. Monthly means (all stations, all dates) of zooplankton biomass $\left(\mathrm{g}(\mathrm{ww}) / \mathrm{m}^{2}\right)$ and C.V. values, during 1969-1985.

\begin{tabular}{ccc}
\hline Month & Biomass $\left(\mathrm{g}(\mathrm{ww}) / \mathrm{m}^{2}\right)$ & Mean C.V. $\times 10^{-2}$ \\
\hline 1 & 40 & 40 \\
2 & 43 & 44 \\
3 & 48 & 48 \\
4 & 38 & 51 \\
5 & 40 & 44 \\
6 & 32 & 36 \\
7 & 22 & 40 \\
8 & 26 & 41 \\
9 & 28 & 36 \\
10 & 23 & 38 \\
11 & 17 & 45 \\
12 & 32 & 43 \\
Grand Mean & 33 & \\
\hline
\end{tabular}

but only Epilimnetic data were filtered for the present study. Original zooplankton data presented here were converted into Biomass units $\left(\mathrm{g}(\mathrm{ww})\right.$ per $\left.\mathrm{m}^{2}\right)$ [12]. The usage of biomass parameters of fish and its food consumption in an ecosystem with respect to long-term impacts is essential. Nevertheless, due to technical difficulties (calibration), fish data is not given by biomass but numerically. The biomass approach to the ecosystem long-term analysis of zooplankton-fish interrelation is essential because fish food (zooplankton) consumption rate is more biomass than numerically dependent. The study was restricted just to the Epilimnion because neither zooplankton nor fish densities in the Hypolimnion are negligible.

Such a retrospective analysis of data, including numerous items, require suitability of statistical methods. Raw date was taped and mean values per station, per periodical intervals (monthly, annual), were computed using indicative parameters of Coefficient of Variation (C.V). CV parameter expresses the Relative Standard Variation (RSD), i.e. the Ratio of the Standard Deviation (SD) to the Mean (X). C.V. shows the extent of variability in relation to the Mean of the population:

$$
\text { C.V. }=\mathrm{SD} / \mathrm{X}
$$

and:

$$
\begin{aligned}
& \text { C.V. }<1=\text { Low Variance } \\
& \text { C.V. }>1=\text { High Variance }
\end{aligned}
$$

Comparative analysis between stations and periods was carried out by Test of significance known as "null hypothesis" which is assessing the strength of the evidence against it. The "null hypothesis" is a definition of "no effect" or "no 
difference". The test of significance calculates the probability (p) of having an outcome at least as far from expected if "no difference" (null hypothesis; $\mathrm{H}_{0}$ ) was true, the computed value of $\mathrm{p}$ (probability) assuming $\mathrm{H}_{0}$ is true. Therefore, the smaller the $\mathrm{p}$-value is, the stronger is the evidence against null hypothesis $\left(\mathrm{H}_{0}\right)$ provided by the data. Practically, if $\mathrm{p}<0.05, \mathrm{H}_{0}$ is rejected, indicating that differences truly existed, and if $p>0.05$, "no difference" is accepted.

\section{Results}

A summary of acoustic surveys carried out in Lake Kinneret during 1987-2005

[2] are presented in Figure 2 and in Figure 3 [3]. The documented data are due to the most (>95\%) common fish size frequencies monitored as $<40-60 \mathrm{~dB}$ Transducer Recordings. These size frequencies are mostly due to Sardine (Lavnun; Mirogrex terraesanctae terraesanctae, Acanthobrama lissneri) and other

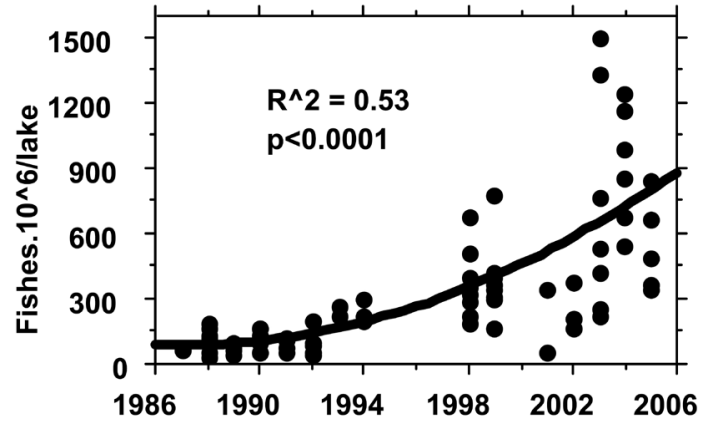

Figure 2. Acoustic surveys in Lake Kinneret during 1987-2005: Polynomial regression ( $\mathrm{p}$ and $\mathrm{r}^{2}$ are given) between All Annual recordings of Fish number and years.

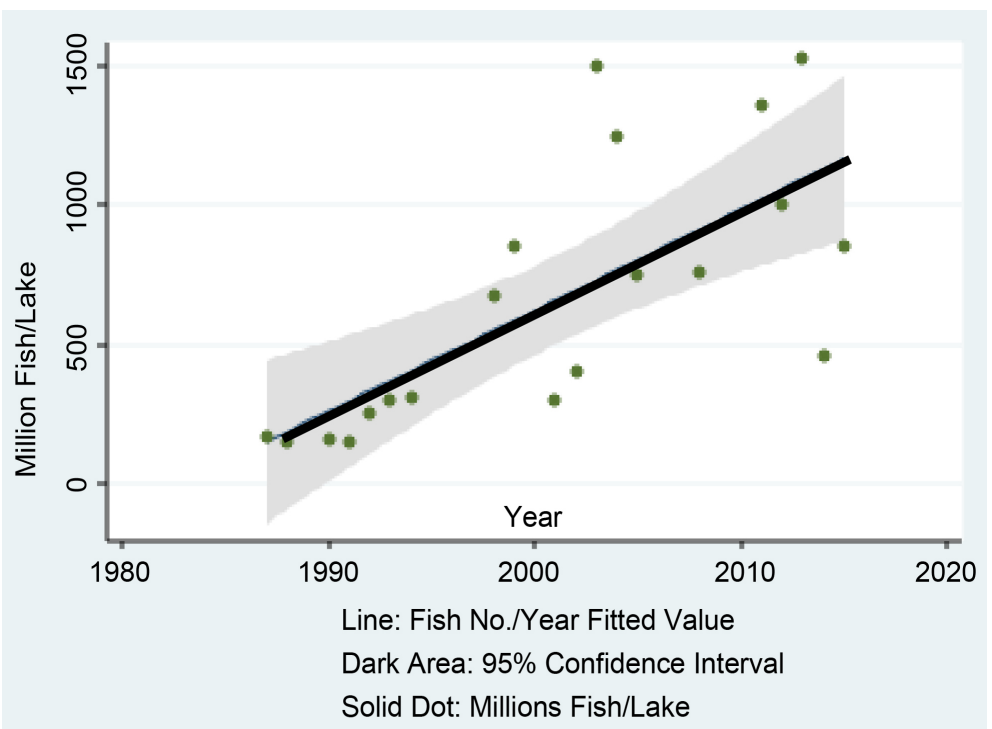

Figure 3. Acoustic surveys in lake Kinneret during 1987-2015: Polynomial regression (Confidence interval is indicated) between annual maximun recorded fish number and year. 
species fingerlings and sub-commercial body length. Larger size frequencies are due to sub-commercial and commercial fishes of about larger than $15 \mathrm{~cm}$ (Total Length) (TL). Zooplankton predation pressure is mostly operated by the small sizes including larvae, fingerlings of all species and adult Sardines [13]-[24]. Presently, some of the Tilapias partly consume zooplankton. The data about stock assessment of fish in Lake Kinneret is given in fish number qualified by Transducer, the acceptance of which is related to numerical density but not biomass. Calibration of $\mathrm{dB}$ to weight (Biomass) was partly carried out during 1987-2005 but not later. Therefore, the analysis of interrelationships between fish and zooplankton is parameterized as Biomass (Zoop.) Vs. Numerical (Fish) densities. Results of Polynomial regression shown in Figure 2 indicate a significant increase of fish densities (95\% are small size frequencies) from the late 1980 's (App. $150 \times 10^{6} /$ lake) to the early 2000's (App. $900 \times 10^{6} /$ lake). Detailed Data of Numerical Fish stock assessment based on Acoustic Survey [2] [3] documented in the Annual Reports of The Kinneret Limnological Laboratory [2] [3] is given in Figure 1 and Figure 2. Fish stock assessment as recorded and calculated was monitored by two different Acoustic Systems with partial temporal overlap; therefore, results are presented in separate Figure 1 and Figure 2: prominent increase of the stock community of fish is indicated since the 2000's. Information given in the Annual Reports of LKDB [1] [2] [3] clearly indicates that the highest densities of small size fishes $(>40-<60 \mathrm{~dB})$ were recorded in the peripheral regions of the lake. Fish assemblages in Lake Kinneret inhabit mostly the peripheral (shallower) zones of the lake. The maps of fish density distribution in Lake Kinneret confirm their very diluted density and they are mostly absent in the pelagic zone of the central and deepest part of the lake [2] [3]. The long-term (1969-2015) record of zooplankton biomass (Figure 4, and [1]) prominently confirms a higher level during 1969-1980 and a decline later. The

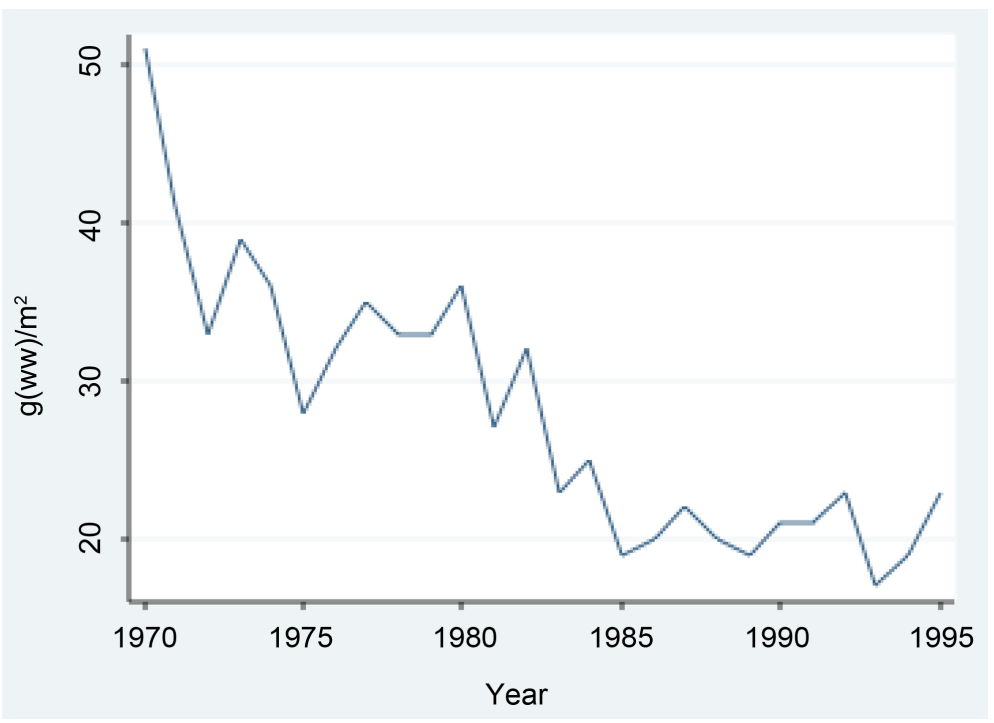

Figure 4. Annual Means of all stations (A)-(G) of zooplankton biomass $\left(\mathrm{g}(\mathrm{ww}) / \mathrm{m}^{2}\right)$. In the epilimnion of lake Kinneret during 1970-1995. 
lake (all stations) averages of zooplankton biomass during the two periods 1970-1982 and 1983-1995 were 35 (SD 6) and 21 (SD 2) $\mathrm{g}(\mathrm{ww}) / \mathrm{m}^{2}$, respectively. Consequently, there is an overlap between the time of the decline of zooplankton biomass and the time the fish stock increase is confirmed. As a result of these observations, a periodical and spatial (station locations) analysis of zooplankton biomass was carried out. Results shown in Figure 5 indicate higher biomass of zooplankton in the central zone than in the peripheral stations of the lake and higher biomass in the Northern region compared to the Southern zone during 1969-1985. The probability value $(\mathrm{p})$ that resulted from a comparative $\mathrm{t}$-test $(\mathrm{p}<$ 0.05 ) between North and South stations indicated clear dissimilarity between those two lake regions. Correlation coefficients $\left(\mathrm{r}^{2}\right)$ between monthly means of zooplankton biomass in all stations (each station Vs. all others) and grand total average were varied within the range of 0.4 - 0.9. Those values of correlation and others shown in Figure 6 indicate mutual ecological parameters other than fish predation which has an impact on zooplankton development. Fractional Polynomial Regressions of station A vs. all other stations, as well as northern Vs southern stations, are significantly similar (left and lower panels Figure 6). Nevertheless, results shown in the upper-left panel (Figure 6) indicate the highest biomass in the central region and higher biomass in the north than in the southern parts of the lake. For the indication of temporal effect, a periodical comparative study of individual stations was carried out (Figures 7-9): Stations D and K (south) (Figure 7), Station A (center) and station G (north) (Figure 8), as well as Stations D, G, and K, (Figure 9 lower left panel) confirm higher biomass in 1969-1985 than in 1986-1995. Moreover, the zooplankton biomass as averaged for the whole lake (Figure 9 upper left panel) and separately (1970-1982 and 19873-1995) clearly indicates the decline of zooplankton biomass from mid-1980's and onwards. Periodical (1:1972-1994; 2: 1995-2005) Linear regression was tested between monthly lake means of zooplankton biomass $(\mathrm{g}(\mathrm{ww}) /$ $\mathrm{m}^{2}$ : LKDB [1]) record and fish stock ( $10^{6}$ fishes /lake; [2] [3]). The result indicates
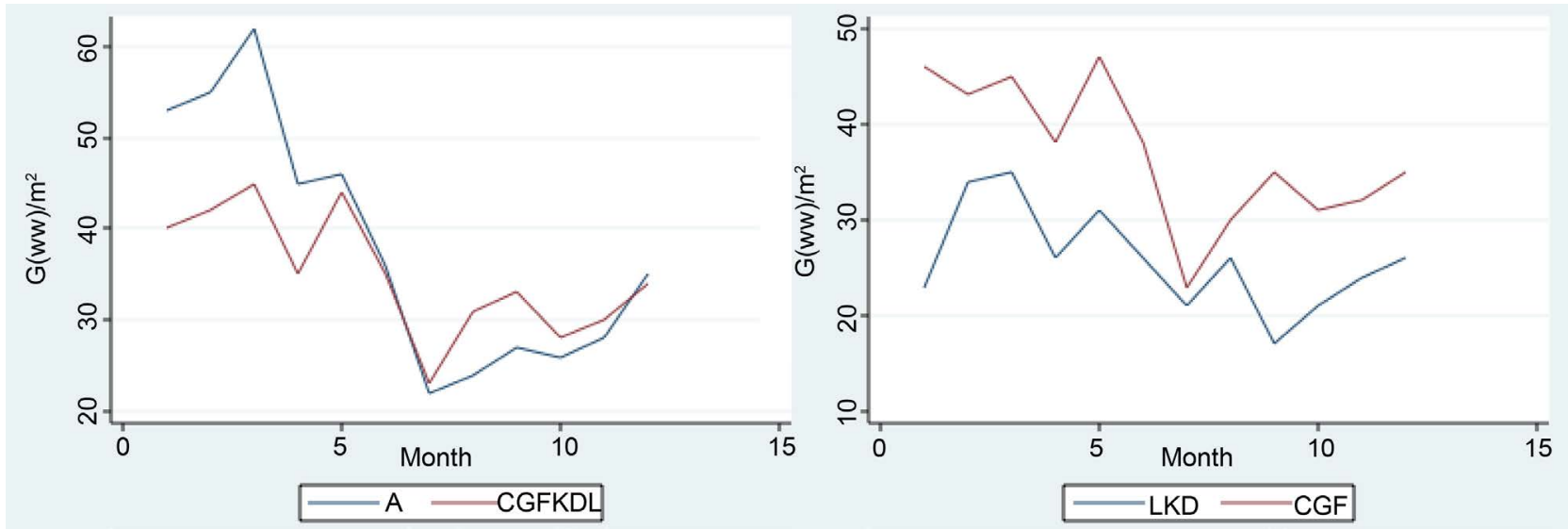

Figure 5. Monthly mean of Epilimnetic zooplankton biomass $\left(\mathrm{g}(\mathrm{ww}) / \mathrm{m}^{2}\right)$ during $1969-1985$, in the Peripherial stations: Southern-L, K, D; Northern-C, G, F. And A (Central). Left: A-Blue (upper), Peripherial-Brown (lower); Wright: Southern-Blue (lower), Northern-Brown (upper). 

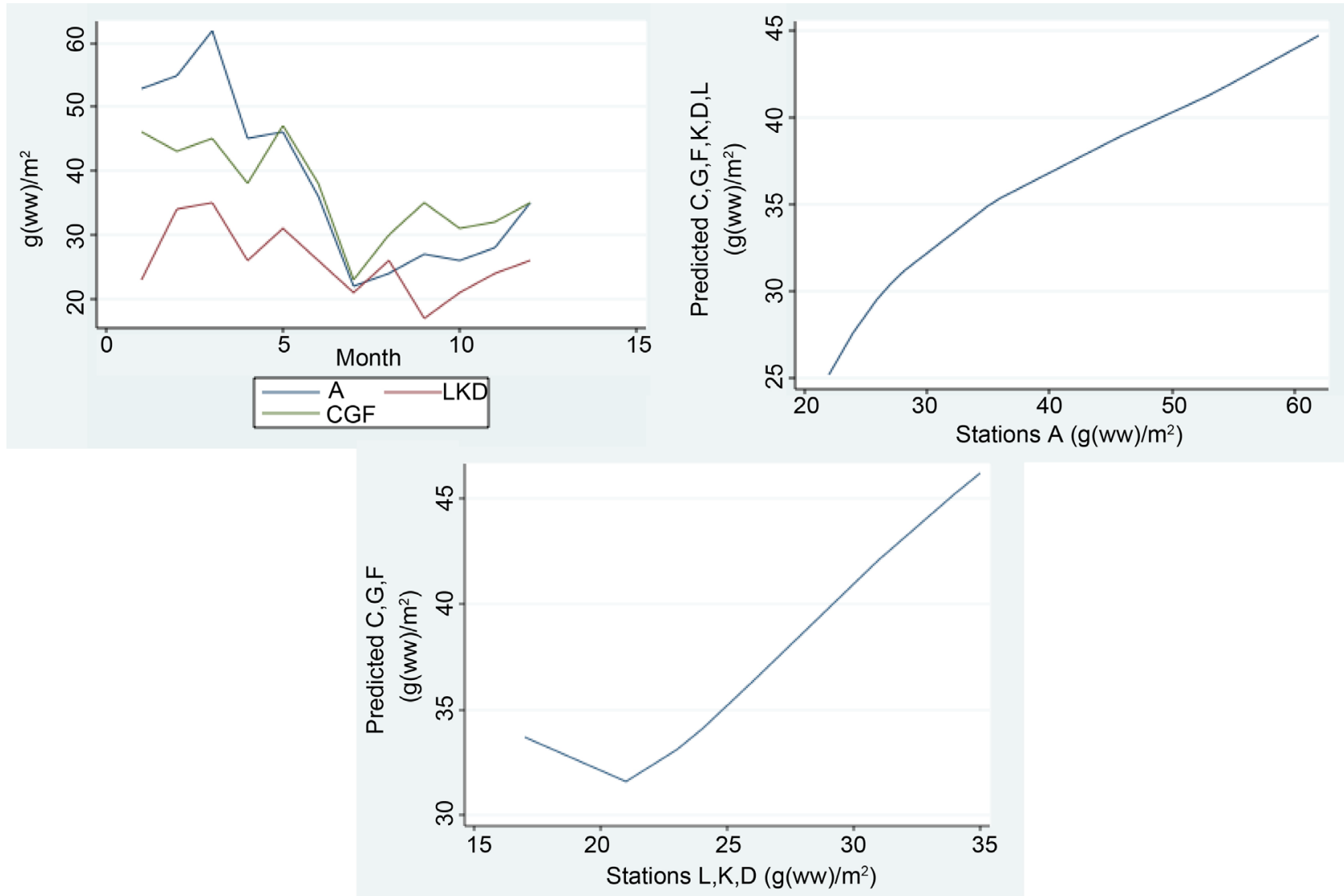

Figure 6. Monthly mean of Epilimnetic zooplankton biomass $\left(\mathrm{g}(\mathrm{ww}) / \mathrm{m}^{2}\right)$ during 1969-1985; Left: in the Peripherial stations: Southern-L, K, D; Northern-C, G, F. And in A (Central); and, Wright: Fractional Polynomial Regression of Station A Vs. all Peripherial stations. Lower: Northern (C, G, F) Vs. Southern (L, K, D).
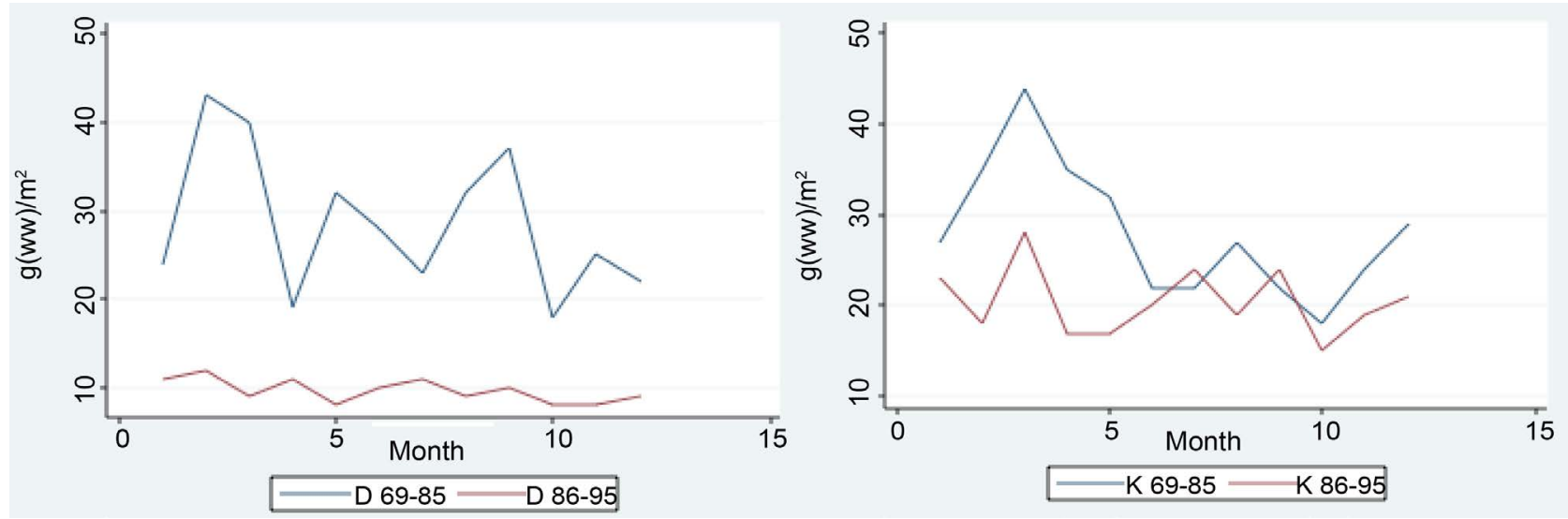

Figure 7. Monthly mean of epilimnetic zooplankton biomass $\left(\mathrm{g}(\mathrm{ww}) / \mathrm{m}^{2}\right)$ during 2 periods: 1969-1985 (Blue) and 1986-1995 (Brown) in two southern peripherial stations: left: station $\mathrm{D}$ and Wright station $\mathrm{K}$.

non-significant $\left(r^{2}=0.0004\right)$ and significant $\left(r^{2}=0.5325\right)$ relations for the earlier and later periods, respectively. Diet composition for Bleak fishes of all ages in Lake Kinneret comprised mostly of Zooplankton. Feeding competition does not exist if food availability is not limited as occurred in the first period and consequently prey-predator stocks are not statistically related. On the contrary, during 

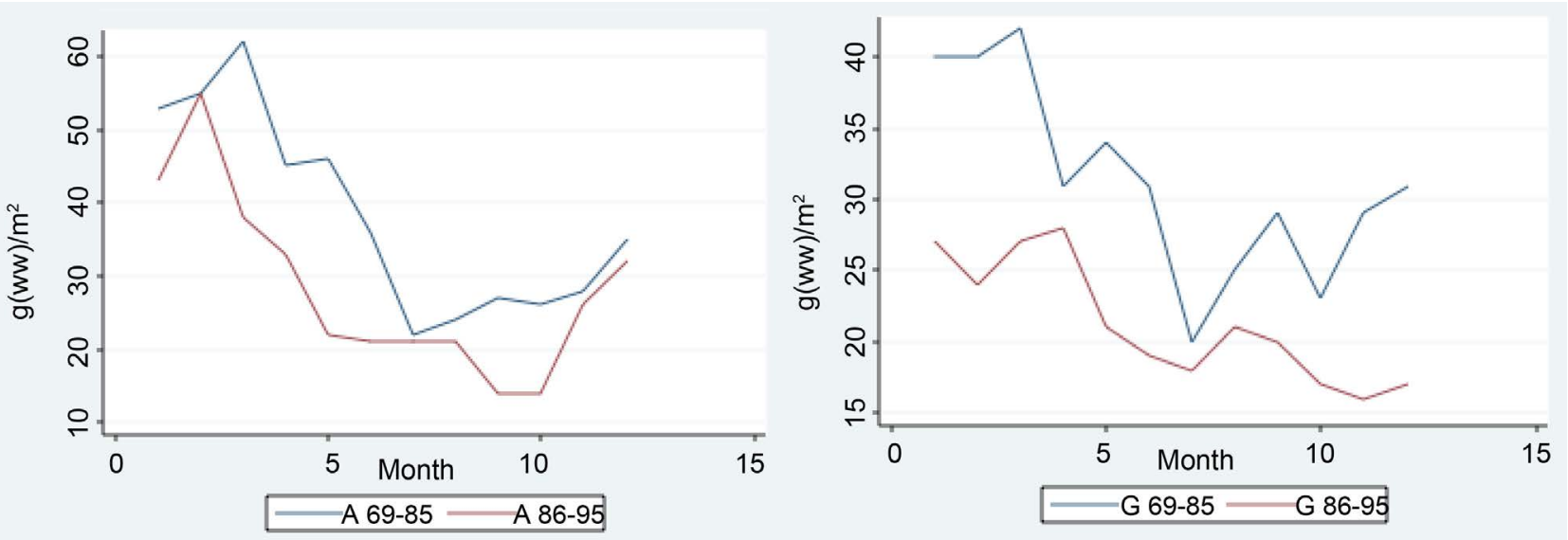

Figure 8. Monthly mean of epilimnetic zooplankton biomass $\left(\mathrm{g}(\mathrm{ww}) / \mathrm{m}^{2}\right)$ during 2 periods: 1969-1985 (Blue) and 1986-1995 (Brown): Left: Station A (Central); Wright: Station G (Peripheral North).
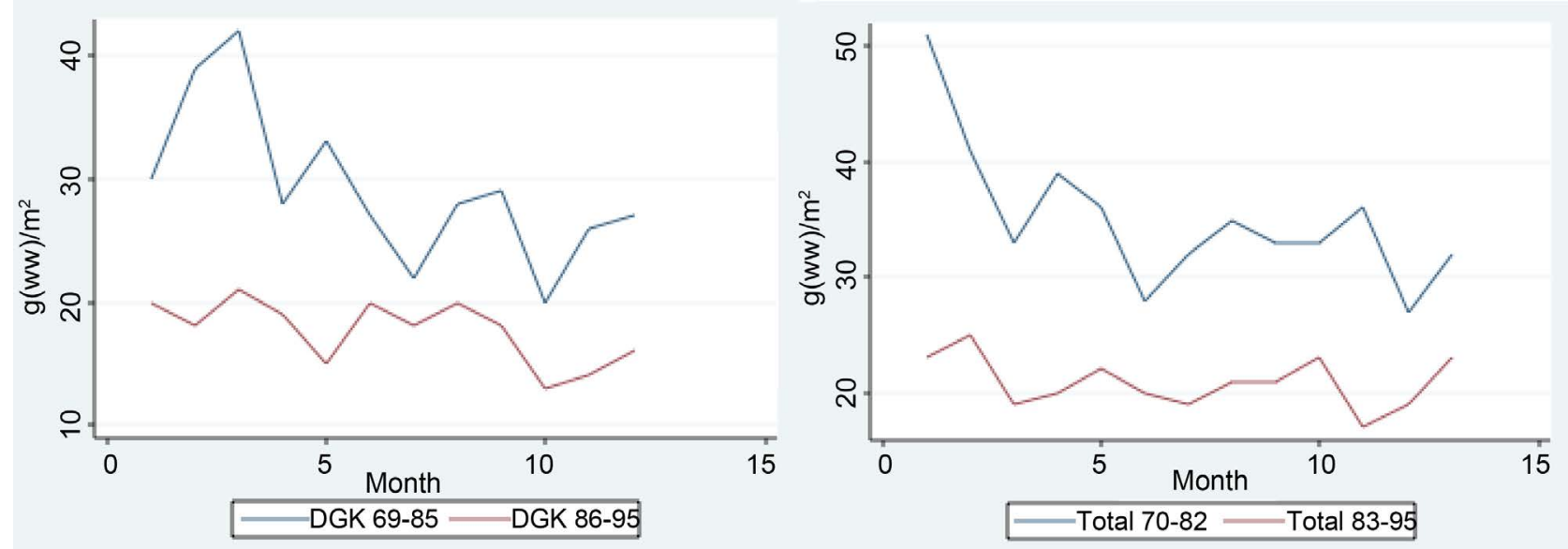

Figure 9. Zooplankton biomass $\left(\mathrm{g}(\mathrm{ww}) / \mathrm{m}^{2}\right)$. Wright: monthly means (all stations) of Epilimnetic zooplankton during two periods: Blue-1970-1982, Brown-1983-1995; Left: Monthly means in Peripherial Stations: Blue-1969-1985; Brown-1986-1995.

the 1995-2005 period, zooplankton biomass significantly declined and fish stock (mostly Bleaks) increased. It is likely that food source became limited and competition forcefully affected, making prey-predator relations significant in the second period.

\section{Discussion}

The inverse relation between Zooplankton Biomass and fish (mostly Bleaks) densities was widely documented in previous studies. An increase of fish densities in the lake started from 1998 (Figure 2) when zooplankton (mostly prey favoured Cladocerans) started a decline [30], Figure 3). Moreover, during 19701993 a significant high harvest (app. 1000 tons per annum) of bleaks was recorded. Probably reflecting a productive stock biomass producing intensive pressure on zooplankton which continuously declined. Nevertheless optimal conditions for zooplankton growth dynamics was indicated except fish predation. Three major factors affecting Zooplankton ecophysiology in Lake Kinneret were 
considered: 1) Food availability; 2) Thermal impact and 3) predatory pressure. The study of herbivore food resources in Lake Kinneret confirmed conditions of no food (algae, protozoa, detritus, and Bacteria) limitation. On the other hand thermal impact was found to have an influence but on a seasonal level and long term fluctuations were too small to produce significan conditional effect. Therefore fish predation was concluded the major factor which is significantly affect fluctuations of Herbivore zooplankton biomass in Lake Kinneret. The research team of the Kinneret Limnological Laboratory started, for the first time in Israel, a comprehensive integrated limnological research of the Lake Kinneret ecosystem in 1968. The research of the zooplankton in the lake was given to the author of this paper. As a collaborative group of scientists, one of their first missions was to fix sampling stations to be followed routinely for the long-term achievement of a monitoring program implementation. This mission was accomplished and the monitoring program operated. The routine monitoring of limnological parameters was directed through those stations from 1969 and continues at present. A daily spatial, bathymetrical and diurnal distribution of zooplankton was previously documented ([1] [4] [6] [7] [8] [9] [10]). Those studies were carried out in a short time range: days and hours. But none of them gave an insight into a multiannual significance of long-term frame. This paper is the first approach to the issue of zooplankton spatial distribution in Lake Kinneret as reflected in 30 years of documentation of routinely collected samples integrated with fish abundance. Ecological factors in Lake Kinneret which have an impact on the natural zooplankton densities were widely explored but the analysis of zooplankton distribution as an outcome from multiannual sample data was never done before. The sampling program is first of all the outcome of available budget and manpower. These two parameters are the limiting factors for the decision about number of stations and frequency of sampling. The requirement for innovated design-based follow-up of the sampling efficiency and relevance to the research objective is obvious and the longer the term of implementation the higher the quality of the decision. The design of the present study advanced through double statistical evaluations: 1) each sampling station annually and monthly; 2) annually and monthly, including all stations. Each one of the analyses was done independently. In other words, the likeness of each station solely as a representative of the whole lake. It was documented in previous studies that zooplankton food availability is optimal and the limiting factors for zooplankton development are temperature and fish predation ([25]-[32]). The natural multiannual (not monthly) fluctuations of the Epilimnetic temperatures are too low to have any significant impact on zooplankton growth rate as confirmed experimentally. Therefore, the abundance of fish in Lake Kinneret was taken as a major impact on the fluctuations of zooplankton density.

The first step in attempting the evaluation of the relation of zooplankton distribution to fish stock data was done by the multiannual fluctuations of both fish and zooplankton densities (Figures 2-4). The data support the suggestion that 
zooplankton decline was due to Fish stock enhancement. The relevance of the measured fish stock size comprises from $>95 \%$ of the recorded targets to small and sub-commercial body sizes which are known as zooplanktivores. Figures 2-4 confirm the inverse relation between Zooplankton density and the documented fish stock.

The second step of the study was an attempt aimed at spatial allocating of fish shoals and zooplankton population. The acoustic surveys clearly confirmed assembling of fish flocks in the peripheral parts of the Kinneret Pelagial. It is, therefore, suggested that zooplanktivory pressure is more intensive in the peripheral stations and lower in the central part of the lake. Consequently, zooplankton biomass is higher in the central parts of the Kinneret pelagial and lower in the peripheral zones. In all stations zooplkankton biomass in winter is higher than in summer. It is the result of the lower energy investment in winter by zooplankton and higher reproduction efficiency [12] [33] [34] together with the lower feeding rate of the fish.

The next step forward in the investigation was due to the dissimilarity of zooplankton density found between the northern and southern parts. Water Current and water-mass moving directions in Lake Kinneret were widely studied and documented as well as the distribution of the Jordan River input waters in the lake [35] [36]. The direction of the flow of the Jordan waters is mostly from the river mouth to the west interlocked in the dominant direction pattern which is anticlockwise. It is suggested that such a current pattern enhances higher densities of Jordan River fluxed suspended particles in the northern stations. Reduction of water clarity by the enhanced concentration of suspended matter also reduces prey (zooplankters) visibility and consequently suppress fish zooplanktivory [37]. The suggested lower concentration of suspended matter in the southern stations (Figure 1) probably enhances zooplankter vulnerability. The outcome is lower zooplankton biomass in the southern part of the Kinneret pelagial. The long-term data record of zooplankton biomass and fish distribution in Lake Kinneret clarified that the previous results are an underestimation. Multi-variable complicated modeling attempts that were carried out aimed at a quantitative chart of energy flow pattern in the Kinneret ecosystem [14] [38] revealed underestimated zooplankton biomass values [31]. The previous data of zooplankton biomass density are based on sampled regions where fish density is high and, therefore, zooplankton predation is intensive. Weighting averages of 7 stations (or even less) where only one of them (Station A, central lake zone) represent most of the Kinneret Epilimnion is fairly unbalanced. Fish density in the central part of the Kinneret Epilimnion is low and the zooplankton biomass is, therefore, high. For a fairly justified representation of the entire lake value, additional sampling stations in the central zone are required. Conclusively, it is therefore suggested to distribute same number of sampling stations for zooplankton study in the peripherial and in the central parts of the Kinneret Pellagial. An alternative option is to give each station a value of aerial coefficient (promo- 
ter) for the calculation of total lake biomass.

\section{Summary and Conclusions}

The grand total average of zooplankton biomass in all sampling stations (A, C, F, $\mathrm{D}, \mathrm{G}, \mathrm{K}, \mathrm{L}$ ) indicates its low level in the peripheral stations and its even lower levels in the southern region of the lake. Conclusively, the design of sampling program aimed at representing the entire Kinneret Pelagial Epilimnion should include at least one station in the southern part (stations D, K, L). If not, the lake mean value will be higher than reality. Furthermore, if sampling program eliminates the central zone (station $\mathrm{A}$ ) the resulting value will be lower than real.

A future suggestion aimed at improvement of zooplankton sampling design is leaving 3 northern and 3 southern peripheral stations and an additional sampling station in the central region south of station A where the depth is about 30 meters.

\section{References}

[1] LKDB-1969-2015, Kinneret Limnological Laboratory, IOLR, Annual Reports.

[2] Walline, P. (1987-2005) Chapter: Fish Communities Survey, In: LKDB, Annual Reports.

[3] Ostrovsky, I. (2006-2015) Chapter: Fish Communities Survey. In: LKDB, Annual Reports.

[4] Gophen, M. (1972) Zooplankton Distribution in Lake Kinneret (Israel) 1969-1970. Israel Journal of Zoology, 21, 17-27.

[5] Gophen, M. (1979) Bathymetrical Distribution and Diurnal Migration of Zooplankton in Lake Kinneret (Israel) with Particular Emphasis on Mesocyclops leuckarti (claus). Hydrobiologia, 64, 199-208. https://doi.org/10.1007/BF00020520

[6] Kalikhman, I., Walline, P. and Gophen, M. (1992) Simultaneous Patterns of Temperature, Oxygen, Zooplankton and Fish Distribution in Lake Kinneret, Israel. Freshwater Biology, 28, 337-347. https://doi.org/10.1111/j.1365-2427.1992.tb00592.x

[7] Kalikhman, Y., Yacobi, Y.Z. and Gophen, M. (2003) Distribution Fields for Aquatic Ecosystem Components: Method of Optimization of Correlation Zones. ICES Journal of Marine Science, 60, 1-10. https://doi.org/10.1006/jmsc.2002.1320

[8] Yacobi, Y.Z., Kalikhman, I., Gophen, M. and Walline, P. (1993) The Spatial Distribution of Temperature, Oxygen, Plankton and Fish Determined Simultaneously in Lake Kinneret, Israel. Journal of Plankton Research, 15, 589-601. https://doi.org/10.1093/plankt/15.6.589

[9] Easton, J. and Gophen, M. (2003) Diel Variations in the Vertical Distribution of Fish and Plankton in Lake Kinneret: A 24-h Study of Ecological Overlap. Hydrobiologia, 491, 91-100. https://doi.org/10.1023/A:1024466600402

[10] Gophen, M. (1978) Errors in the Estimation of Recruitment of Early Stages of $\mathrm{Me}$ socyclops leuckarti (Claus) Caused by the Diurnal Periodicity of Egg Production. Hydrobiologia, 57, 59-64. https://doi.org/10.1007/BF00018628

[11] Gophen, M. (1978) The Productivity of Mesocyclops leuckarti (Claus) in Lake Kinneret (Israel). Hydrobiologia, 60, 17-22. https://doi.org/10.1007/BF00018683

[12] Gophen, M. and Azoulay, B. (2002) The Trophic Status of Zooplankton Communi- 
ties in Lake Kinneret (Israel). Verhandlungen des Internationalen Verein Limnologie, 28, 836-839.

[13] Gophen, M. and Landau, R. (1977) Trophic Interactions between Zooplankton and Sardine (Mirogrex terraesanctae) Populations in Lake Kinneret, Israel. Oikos, 29, 166-174. https://doi.org/10.2307/3543309

[14] Serruya, C., Gophen, M. and Pollingher, U. (1980) Lake Kinneret: Carbon Flow Patterns and Ecosystem Management. Archiv für Hydrobiologie, 88, 265-302.

[15] Drenner, R.W., Vinyard, G.L., Gophen, M. and McComas, S.R. (1982) Feeding Behaviour of the Cichlid Sarotherodon galilaeus: Selective Predation on Lake Kinneret Zooplankton. Hydrobiologia, 87, 17-20. https://doi.org/10.1007/BF00016658

[16] Gophen, M., Drenner, R.W. and Vinyard, G.L. (1983) Cichlid Stocking and the Decline of the Galilee St. Peter's Fish (Sarotherodon galilaeus) in Lake Kinneret (Israel). Canadian Journal of Fisheries and Aquatic Sciences, 40, 983-986. https://doi.org/10.1139/f83-124

[17] Gophen, M. (1985) Effect of Fish Predation on Size Class Distribution of Cladocerans in Lake Kinneret. Verhandlungen des Internationalen Verein Limnologie, 22, 3104-3108.

[18] Gophen, M. and Pollingher, U. (1985) Relationships between Food Availability, Fish Predation and the Abundance of the Herbivorous Zooplankton Community in Lake Kinneret. Archiv für Hydrobiologie-Beiheft Ergebnisse der Limnologie, 21, 397-405.

[19] Vinyard, G.L., Drenner, R.W., Gophen, M., Pollingher, U., Winkleman, D.L. and Hambright, K.D. (1988) An Experimental Study of the Plankton Community Impacts of Two Filter-Feeding Cichlids, The Galilee Saint Peter's Fish (Sarotherodon galilaeus) and Blue Tilapia (Tilapia aurea). Canadian Journal of Fisheries and Aquatic Sciences, 45, 685-690. https://doi.org/10.1139/f88-082

[20] Landau, R., Gophen, M. and Walline, P. (1988) Larval Mirogrex terraesanctae (Cyprinidae) of Lake Kinneret (Israel): Growth Rate, Plankton Selectivities, Consumption Rates and Interactions with Rotifers. Hydrobiologia, 169, 91-106. https://doi.org/10.1007/BF00007937

[21] Gophen, M. and Threlkeld, S.T. (1989) An Experimental Study of Zooplankton Consumption by the Lake Kinneret Sardine. Archiv fur Hydrobiologie, 115, 91-95.

[22] Azoulay, B. and Gophen, M. (1992) Feeding Habits of Larval Mirograx terraesanctae (Steinitz 1952) in Lake Kinneret (Israel): I. Field Study. Hydrobiologia, 246, $243-$ 249. https://doi.org/10.1007/BF00005701

[23] Azoulay, B. and Gophen, M. (1992) Feeding Habits of Larval Mirograx terraesanctae (Steinitz 1952) in Lake Kinneret (Israel): II. Experimental Study. Hydrobiologia, 246, 251-258. https://doi.org/10.1007/BF00005702

[24] Easton, J. and Gophen, M. (2002) Trophic Relations between Zooplankton and Bleaks (Acanthobrama spp.) in Lake Kinneret (Israel). Verhandlungen des Internationalen Verein Limnologie, 28, 1258-1261.

[25] Gophen, M. (1976) Temperature Dependence of Food Intake, Ammonia Excretion and Respiration in Ceriodaphnia reticulata (Jurine) (Lake Kinneret, Israel). Freshwater Biology, 6, 451-455.

[26] Gophen, M. (1976) Temperature Effect on Lifespan, Metabolism and Development time of Mesocyclops leuckarti (Claus). Oecologia, 25, 271-277. https://doi.org/10.1007/BF00345104

[27] Gophen, M. (1992) Long-Term Changes of Plankton-Communities in Lake Kinneret, Israel. Asian Fisheries Science, 5, 291-302. 
[28] Gophen, M. (2013) The Impact of Temperature Elevation on the Decline of Cyclopoid Population in Lake Kinneret (Israel). The Journal of Ecology Photon, 107, 223-239.

[29] Gophen, M. (2015) Thermal Preference by Mesocyclops ogunnus (Onabamiro 1957). Open Journal of Ecology, 5, 15-21. https://doi.org/10.4236/oje.2015.52002

[30] Gophen, M. (2015) Ecophysiology of Lake Kinneret (Israel) Zooplankton. Earth \& Environmental Sciences, 5, 187-198. https://doi.org/10.4236/oje.2015.55016

[31] Gophen, M. (2016) Scientific Values Are Crucial for Lake Kinneret Management Design: Test Cases. Engineering Management Research, 5, 12-21. https://doi.org/10.5539/emr.v5n1p12

[32] Gophen, M. (2017) Search for Environmental Causation of the Cladoceran Dynamics in Lake Kinneret, Israel. Open Journal of Modern Hydrology, 7, 90-104. https://doi.org/10.4236/ojmh.2017.72005

[33] Gophen, M. (1978) Zooplankton. In: Serruya, C., Ed., Lake Kinneret, Monographiae Biologicae, Vol. 32, Dr. W. Junk Publishers, The Hague, 297-311. https://doi.org/10.1007/978-94-009-9954-1_11

[34] Gophen, M. (1981) Metabolic Activity of Herbivorous Zooplankton in Lake Kinneret (Israel) during 1972-1977. Journal of Plankton Research, 3, 15-24. https://doi.org/10.1093/plankt/3.1.15

[35] Serruya, S. (1974) The Mixing Pattern of the Jordan River in Lake Kinneret. Limnology and Oceanography, 19, 175-181. https://doi.org/10.4319/lo.1974.19.2.0175

[36] Serruya, S. (1978) Chapter: Water Motions. In: Serruya, C. Ed., Lake Kinneret, Monographiae Biologicae, Vol. 32, Junk Publishers, The Hgue, Boston, London, 167172. https://doi.org/10.1007/978-94-009-9954-1

[37] Gophen, M. (2015) The Impact of Turbidity on Zooplanlkton Densities in Lake Kinneret (Israel). Open Journal of Modern Hydrology, 5, 87-94.

[38] Walline, P., Pizanty, S., Gophen, M. and Berman, T. (1990) The Ecosystem of Lake Kinneret, Israel. ICES.C.M. 1990/L:39, 1-8.

Submit or recommend next manuscript to SCIRP and we will provide best service for you:

Accepting pre-submission inquiries through Email, Facebook, LinkedIn, Twitter, etc. A wide selection of journals (inclusive of 9 subjects, more than 200 journals)

Providing 24-hour high-quality service

User-friendly online submission system

Fair and swift peer-review system

Efficient typesetting and proofreading procedure

Display of the result of downloads and visits, as well as the number of cited articles

Maximum dissemination of your research work

Submit your manuscript at: http://papersubmission.scirp.org/

Or contact ojmh@scirp.org 